\title{
Prevalence of teat end hyperkeratosis in lactating dairy cattle and their association with animal variables
}

\author{
Hilke Haverkamp ${ }^{1}$, Jan-Hendrik Paduch ${ }^{2}$, Doris Klocke ${ }^{3}$, Martina Hoedemaker ${ }^{4}$, \\ Volker Krömker ${ }^{5}$ \\ ${ }^{1,2,3,5}$ University of Applied Sciences and Arts, Faculty II Mechanical and Bioprocess Engineering, Heisterbergallee10a, \\ 30453 Hannover \\ ${ }^{4}$ Cattle Clinic, Hanover University of Veterinary Medicine, Foundation, Bisch of sholer Damm 25, 30161 Hannover
}

\begin{abstract}
Short and long-term changes in teat condition mainly caused by machine milking may affect the udder health of lactating dairy cattle. The objective was to investigate the prevalence of teat end hyperkeratosis scores in lactating dairy cattle in Germany and to determine associations between animal variables and teat end hyperkeratosis. The study was conducted in 15 German high-yielding dairy herds. On dairy farms teat size, teat shape, teat end shape and changes in teat condition (edema, teat skin colour, teat end hyperkeratosis) were recorded. In total, 4,022 animals of the breed German Holstein were included into the present study. For both front and rear teats associations between teat end hyperkeratosis and lactation number, teat length, teat diameter and teat end shape were found. Further research is needed to reduce the prevalence of teat end hyperkeratosis in high-yielding dairy herds and to improve the teat condition.
\end{abstract}

Keywords - Udder health, teat end hyperkeratosis, teat end shape.

\section{INTRODUCTION}

Udder health problems cause huge economic loss in dairy milk production. Estimates put the amount of lost milk caused by raised somatic cell counts at 3 to $18 \%$ for cows with an average somatic cell count of 500,000 cells $/ \mathrm{ml}$ [1]. Clinical mastitis is even more costly through discarded milk and treatment costs [2].

Poor teat condition is identified to be a risk factor for udder health problems in modern dairy herds. Authors categorize changes in teat end condition in three major groups: short term, medium term, and long term changes in teat condition [3]. Short and medium term changes like congestion, edema, swelling of the teat base and petechia are clinical signs of an impaired circulation of blood and lymph. Teat end hyperkeratosis is a so called long term change of the teat tissue [3]. In general, teat tissue changes are a result of mechanical stress affecting the tissue during machine milking [4]. Main risk factors for changes in teat condition are long machine-on times [4, 5, 6], high vacuum levels [7, 8, 9] and overmilking [10, 11, 12].Additionally cow individual risk factors are described by several authors for extreme teat end hyperkeratosis. These factors are teat size [13] and teat end shape [14, 15]. Teat end hyperkeratosis may influence the prevalence of intramammary infections $[16,17]$.

Mein et al. (2001) also tried to confirm thresholds for the interpretation of the teat end condition found in dairy herds [3].They recommend that less than $20 \%$ animals have teats with teat end hyperkeratosis exceeding the severity of a smooth white ring around the teat orifice.

The aim of this study was to describe the prevalence of teat end conformation traits including cow individual variables like teat size and teat end shape and milking induced teat tissue changes, especially teat end hyperkeratosis in high-yielding German dairy herds. Associations between cow individual variables and teat end hyperkeratosis were examined.

\section{MATERIAL AND METHODS}

\subsection{Farms and animals}

The animals used for this survey originated from 15 randomly selected dairy herds in Northern Germany. The selected farms kept cows of the breed German Holstein black pied and had an average milk yield of at least 9,000 kg per cow and year. Milking equipment of each farm was tested according to ISO 5707:1996 once a year [18]. The majority of cows in the herds were enrolled in this study. Animals with apparent signs of a clinical mastitis, especially with an inflammatory swelling of the affected quarter were excluded from the study. 


\subsection{Data collection}

Data collection was performed between May and October 2014. The participating farms were visited once and animals were examined during milking time. Observations were done by trained, constant teams of two persons, to gather reliable results. Teat size (length, diameter $1 \mathrm{~cm}$ proximal the teat end) as well as teat shape and teat end shape [19] were determined before milking (Table 1). Immediately after cluster detachment short and long-term changes in teat condition of the right front and the right rear teat of each cow were examined visually and by manual palpation according to Mein et al. (2001) [3].

\section{TABLE 1}

ANIMAL VARIABLES INCLUDED INTO THE INVESTIGATIONS

\begin{tabular}{|c|c|c|}
\hline Criterion & Mode of detection & Score/category \\
\hline \multicolumn{3}{|c|}{ Teat size } \\
\hline Teat length & measuring & $\begin{array}{c}\text { from the base of the teat to the } \\
\text { teat tip }\end{array}$ \\
\hline Teat diameter & measuring & $1 \mathrm{~cm}$ above the teat tip \\
\hline \multicolumn{3}{|c|}{ Teat and teat end shape (Grunert et al., 1990) } \\
\hline Teat shape & visual & $\begin{array}{c}\text { normal } \\
\text { meat } \\
\text { short } \\
\text { funnel } \\
\text { pencil } \\
\text { broke } \\
\text { bottle }\end{array}$ \\
\hline Teat end shape & visual & $\begin{array}{l}\text { round } \\
\text { flat } \\
\text { inverted } \\
\text { pocket } \\
\text { pointed }\end{array}$ \\
\hline \multicolumn{3}{|c|}{ Short-term changes in teat condition (Mein et al., 2001) } \\
\hline Colour of the teat skin & visual & $\begin{array}{c}\text { pale, pale-rose, rose, rose-blue, } \\
\text { blue }\end{array}$ \\
\hline Swelling of the teat base & visual / palpation & yes/no \\
\hline Oedema of the teat & palpation & $\begin{array}{c}\text { no oedema } \\
\text { swelling of teat end } \\
\text { swelling of teat barrel }\end{array}$ \\
\hline \multicolumn{3}{|c|}{ Long-term changes in teat condition (Mein et al., 2001) } \\
\hline Teat end hyperkeratosis & visual & $\begin{array}{c}0 \text { no callous rings } \\
1 \text { smooth, slightly raised ring } \\
2 \text { rough raised ring } \\
3 \text { rough raised ring, fronds }\end{array}$ \\
\hline
\end{tabular}

Lactation number and lactation stage data (days in milk) of the animals included into the present study were collected from cattle herd software.

\subsection{Statistical analysis}

Data were gathered and analysed using the programmes Microsoft Excel, Microsoft Access 2000 (Microsoft Corporation), and SPSS (SPSS 23.0, Chicago USA). The udder quarter was the statistical unit. The associations between hyperkeratosis and animal variables (covariates, factors) were analysed using ordinal regression procedures [20]. The teat end hyperkeratosis score was the dependent variable. The relationships between single animal variables and teat end hyperkeratosis were tested using ANOVA test for continuous measurements and the $\chi^{2}$-test (likelihood ratio statistic) for proportions in a first step. However, predictors that strongly correlated with each other ( $r>0.70)$ were not included in the same model to avoid multicollinearity. As a second step, variables that were associated with the outcome variables at $\mathrm{P}<$ 0.10 in ANOVA for continuous measurements and the $\chi^{2}$-test for proportions were included in ordinal logistic regressions. A 
forward stepwise process was used for final model selection, applying a $\mathrm{P}$ value $<0.05$ for inclusion. Likelihood-ratio tests were used for significance test to include predictors. Goodness of fit of models was assessed by Pearsons $\chi^{2}$ goodness of fit statistics [21]. The predictive power of a model was measured by a rescaled pseudo $\mathrm{R}^{2}$ with the maximum of 1 [22]. Statistical significance was assumed at $\mathrm{P} \leq 0.05$.

\section{RESULTS AND DISCUSSION}

\subsection{Descriptive statistics}

4,022 animals from 15 dairy farms were enclosed in this survey per farm between 69 and 848 animals were included into the present study. In total 4,022 front teats and 4,022 rear teats were investigated.

\subsection{Teat end hyperkeratosis score}

The distribution for the different teat end hyperkeratosis scores is shown in Table 2. The most prevalent finding was score 1 (smooth white ring around the teat orifice). 53.74\% of the front teats and $47.38 \%$ of the rear teats exceeded the extent of a smooth white ring (score $2+$ score 3 ). The hyperkeratosis of $20.06 \%$ of the front and $15.71 \%$ of the rear teats was classified as score 3 .

TABLE 2

ANIMAL VARIABLES IN THE NORTHERN GERMAN DAIRY CATTLE POPULATION INCLUDED INTO THE PRESENT STUDY ( $=4,022$ ANIMALS) (mean \pm standard deviation and frequency, respectively)

\begin{tabular}{|c|c|c|c|}
\hline Animal variable & & Front teats & Rear teats \\
\hline Lactation stage (days in milk) & & \multicolumn{2}{|c|}{$203 \pm 135$} \\
\hline \multirow{2}{*}{ Teat size $(\mathrm{mm})$} & length & $53.5+/-8.1$ & $46.4+/-7.6$ \\
\hline & diameter & $21.7+/-2.6$ & $21.3+/-2.6$ \\
\hline \multirow{2}{*}{ Teat shape $(\%)$} & normal & 99.09 & 99.57 \\
\hline & other shape & 0.91 & 0.43 \\
\hline \multirow{5}{*}{ Teat end shape $(\%)$} & round & 81.01 & 81.08 \\
\hline & flat & 13.79 & 14.13 \\
\hline & pointed & 3.81 & 3.44 \\
\hline & funnel shaped & 1.39 & 1.34 \\
\hline & other shape than round & 18.99 & 18.91 \\
\hline \multirow{3}{*}{ Teat edema $(\%)$} & no & 21.90 & 18.86 \\
\hline & teat barrel & 45.70 & 44.58 \\
\hline & teat end & 32.40 & 36.56 \\
\hline \multirow{2}{*}{ Swelling at teat base $(\%)$} & no & 76.26 & 69.19 \\
\hline & yes & 23.74 & 30.81 \\
\hline \multirow{2}{*}{ Teat skin colour $(\%)$} & rose & 56.27 & 56.14 \\
\hline & other colour than rose & 43.73 & 43.86 \\
\hline \multirow{5}{*}{$\begin{array}{l}\text { Teat end hyperkeratosis } \\
\text { Score }(\%)\end{array}$} & 0 & 6.27 & 7.27 \\
\hline & 1 & 39.99 & 45.36 \\
\hline & 2 & 33.68 & 31.67 \\
\hline & 3 & 20.06 & 15.71 \\
\hline & $2+3$ & 53.74 & 47.38 \\
\hline
\end{tabular}

\subsection{Lactation number}

On average, cows included in the study had 2 to 3 lactations (minimum: 1 lactation, maximum: 12 lactations).

\subsection{Lactation stage}

Cows were on average $203 \pm 135$ days in milk (Table 3). 


\section{TABLE 3}

\section{MEAN VALUES \pm STANDARD DEVIATION (RANGE) OF ANIMAL VARIABLES INCLUDED INTO THE FINAL} LOGISITIC REGRESSION MODELS

\begin{tabular}{|c|c|c|c|c|c|c|c|c|}
\hline \multirow{3}{*}{ Animal variable } & \multicolumn{8}{|c|}{ Teat end hyperkeratosis score } \\
\hline & \multicolumn{4}{|c|}{ Front teats } & \multicolumn{4}{|c|}{ Rear teats } \\
\hline & 0 & 1 & 2 & 3 & $\mathbf{0}$ & 1 & 2 & 3 \\
\hline \multirow{2}{*}{ Lactation number } & $2.27+/-1.30$ & $2.09+/-1.34$ & $2.18+/-1.38$ & $2.32+/-1.32$ & $2.33+/-1.34$ & $2.14+/-1.36$ & $2.24+/-1.41$ & $2.44+/-1.37$ \\
\hline & $(1-7)$ & $(1-11)$ & $(1-12)$ & $(1-8)$ & $(1-7)$ & $(1-12)$ & $(1-10)$ & $(1-8)$ \\
\hline \multirow{2}{*}{$\begin{array}{c}\text { Lactation stage } \\
\text { (days in milk) }\end{array}$} & $206+/-154$ & $196+/-131$ & $207+/-137$ & $222+/-148$ & $182+/-143$ & $196+/-132$ & $212+/-135$ & $216+/-135$ \\
\hline & $(2-774)$ & $(3-886)$ & $(1-786)$ & $(1-743)$ & $(2-774)$ & $(3-886)$ & $(1-786)$ & $(1-721)$ \\
\hline \multirow{2}{*}{ Teat length (mm) } & $51.3+/-8.1$ & $52.6+/-8.1$ & $53.3+/-7.9$ & $55.4+/-7.9$ & $45.0+/-7.7$ & $45.8+/-7.6$ & $46.4+/-7.3$ & $49.0+/-7.4$ \\
\hline & $(35-78)$ & $(30-92)$ & $(30-88)$ & $(37-81)$ & $(25-73)$ & $(22-94)$ & $(15-80)$ & $(22-80)$ \\
\hline \multirow{2}{*}{$\begin{array}{l}\text { Teat diameter } \\
(\mathrm{mm})\end{array}$} & $22.4+/-2.7$ & $21.7+/-2.7$ & $21.7+/-2.6$ & $21.8+/-2.5$ & $21.8+/-2.3$ & $21.2+/-2.6$ & $21.1+/-2.3$ & $21.5+/-3.1$ \\
\hline & $(17-35)$ & $(10-44)$ & $(16-43)$ & $\begin{array}{l}(15-45) \\
\end{array}$ & $(17-31)$ & $(10-35)$ & $(14-33)$ & $(16-35)$ \\
\hline
\end{tabular}

\subsection{Teat length and teat diameter}

Average teat length found for the investigated dairy cows was $53.5+/-8.1$ (mean $+/$ - standard deviation) $\mathrm{mm}$ for front and $46.4+/-7.6 \mathrm{~mm}$ for rear teats. The teat diameter found had an average value of $21.7+/-2.6 \mathrm{~mm}$ for front teats and of $21.3+/-$ $2.6 \mathrm{~mm}$ for the rear teats (table 2).

\subsection{Teat shape}

$99.09 \%$ of the front and $99.57 \%$ of the rear teats were found to have a normal teat shape.

\subsection{Teat endshape}

A round teat end was the most common teat endshape found in front and rear teats (over $80 \%$ ) followed by flat teat ends (13.79\% and $14.13 \%$ for front and rear teats, respectively) and pointed teat ends (3.81\% and $3.44 \%$ ) (Table 2). An association could be found for teat end shape and hyperkeratosis in front and rear teats. Teats with hyperkeratosis score $3 \mathrm{had}$ round teat ends in $85 \%$ of all cases, more than $5 \%$ of the teats were flat and more than $7 \%$ had a pointed teat end (Table 4 ).

TABLE 4

PERCENTAGE DISTRIBUTION OF ANIMAL VARIABLES TO HYPERKERATOSIS SCORES $(\mathrm{n}=\mathbf{4 , 0 2 2}$ animals) $(\%)$

\begin{tabular}{|c|c|c|c|c|c|c|c|c|c|}
\hline \multirow{3}{*}{$\begin{array}{c}\text { Animal } \\
\text { variable }\end{array}$} & & \multicolumn{8}{|c|}{ Teat end hyperkeratosis score } \\
\hline & & \multicolumn{4}{|c|}{ Front teats } & \multicolumn{4}{|c|}{ Rear teats } \\
\hline & & 0 & 1 & 2 & 3 & $\overline{0}$ & 1 & 2 & 3 \\
\hline \multirow{2}{*}{ Udder shape } & normal & 97.79 & 99.51 & 98.87 & 98.61 & 98.06 & 99.49 & 98.90 & 98.45 \\
\hline & other shape & 2.21 & 0.49 & 1.13 & 1.39 & 1.94 & 0.51 & 1.10 & 1.55 \\
\hline \multirow{2}{*}{ Udder edema } & no & 96.90 & 99.43 & 99.69 & 99.83 & 97.29 & 99.49 & 99.67 & 99.78 \\
\hline & yes & 3.10 & 0.57 & 0.31 & 0.17 & 2.71 & 0.51 & 0.33 & 0.22 \\
\hline \multirow{2}{*}{ Intertrigo } & no & 99.56 & 99.92 & 99.90 & 99.65 & 99.61 & 99.93 & 99.89 & 99.56 \\
\hline & yes & 0.44 & 0.08 & 0.10 & 0.35 & 0.39 & 0.07 & 0.11 & 0.44 \\
\hline \multirow{2}{*}{ Teat shape } & normal & 98.35 & 99.36 & 99.00 & 99.23 & 99.64 & 99.77 & 99.43 & 99.51 \\
\hline & Other shape & 1.65 & 0.64 & 1.00 & 0.77 & 0.36 & 0.23 & 0.57 & 0.49 \\
\hline \multirow{5}{*}{ Teat end shape } & round & 73.66 & 79.35 & 82.19 & 85.84 & 76.51 & 80.31 & 81.33 & 86.63 \\
\hline & flat & 20.16 & 16.52 & 13.20 & 5.79 & 17.44 & 16.15 & 14.00 & 5.12 \\
\hline & pointed & 0.41 & 2.32 & 3.99 & 7.85 & 0.36 & 2.17 & 4.10 & 7.59 \\
\hline & funnel shaped & 5.76 & 1.81 & 0.61 & 0.51 & 5.69 & 1.37 & 0.57 & 0.66 \\
\hline & other than round & 26.34 & 20.65 & 17.81 & 14.16 & 23.49 & 19.69 & 18.67 & 13.37 \\
\hline \multirow{3}{*}{ Teat edema } & no & 24.17 & 24.10 & 21.37 & 17.31 & 25.91 & 19.56 & 17.57 & 15.25 \\
\hline & teat barrel & 33.75 & 30.52 & 33.70 & 32.50 & 35.77 & 36.08 & 36.91 & 36.61 \\
\hline & teat tip & 42.08 & 45.38 & 44.93 & 50.20 & 38.32 & 44.37 & 45.52 & 48.14 \\
\hline \multirow{2}{*}{$\begin{array}{l}\text { Swelling at teat } \\
\text { base }\end{array}$} & no & 79.41 & 75.38 & 76.55 & 77.30 & 75.45 & 67.28 & 69.47 & 71.48 \\
\hline & yes & 20.59 & 24.62 & 23.45 & 22.70 & 24.55 & 32.72 & 30.53 & 28.52 \\
\hline \multirow{2}{*}{ Teat skin } & dry & 97.22 & 96.00 & 94.43 & 95.71 & 97.51 & 95.57 & 95.04 & 94.99 \\
\hline & wet & 2.78 & 4.00 & 5.57 & 4.29 & 2.49 & 4.43 & 4.96 & 5.01 \\
\hline \multirow{2}{*}{ Teat skin color } & rose & 61.45 & 59.49 & 52.79 & 54.08 & 63.72 & 56.88 & 54.45 & 53.85 \\
\hline & others & 38.55 & 40.51 & 47.21 & 45.92 & 36.28 & 43.12 & 45.55 & 46.15 \\
\hline
\end{tabular}




\subsection{Short term changes in teat condition}

The presence of short term changes in teat condition like teat edema, swelling at the teat base and teat skin color have been investigated. $45.7 \%$ of the front and $44.58 \%$ of the rear teats had an edema of the teat barrel. $32.40 \%$ of the front and $36.56 \%$ of the rear teats had an edema of the teat end. A swelling at the teat base was found for $23.74 \%$ of the front and $30.81 \%$ of the rear teats. The teat skin of $43.73 \%$ of the front and $43.86 \%$ of the rear teats were rose-blue or blue.

\subsection{Final logistic regression model}

Table 5 provides the final regression models for hyperkeratosis as dependent variable. The rescaled $\mathrm{R}^{2}$ of the final models were 0.226 and 0.281 for front and rear quarters, respectively. The goodness of fit-statistic did not give any reason to doubt about the validity of the models (front teats: $\mathrm{P}=0.366$; rear teats: $\mathrm{P}=0.560$ ). Significant animal variables associated with hyperkeratosis identified by the final logistic regression model for front and rear quarters were "teat length", "teat diameter", "teat end shape" and "lactation number".

\section{TABLE 5}

FINAL ORDINAL REGRESSION MODELS FOR SIGNIFICANT ANIMAL VARIABLES ASSOCIATED WITH TEAT END HYPERKERATOSIS $(\mathrm{n}=\mathbf{4 , 0 2 2}$ animals)

\begin{tabular}{|c|c|c|c|c|c|c|}
\hline & Variable & Estimate & SE & $\mathbf{P}$ & Wald & $95 \% \mathrm{CI}$ \\
\hline \multirow{8}{*}{ Front teats } & lactation no. & 0.044 & 0.016 & 0.007 & 7.349 & $0.012-0.076$ \\
\hline & Teat length & 0.017 & 0.003 & $<0.001$ & 34.603 & $0.011-0.023$ \\
\hline & Teat diameter & ---0.020 & 0.008 & 0.014 & 6.069 & $-0.037--0.004$ \\
\hline & \multicolumn{3}{|c|}{ Teat end shape } & & & \\
\hline & round & 0.809 & 0.191 & 0.004 & 17.864 & $0.434-1.184$ \\
\hline & pointed & 1.292 & 0.219 & 0.017 & 34.734 & $0.862-1.721$ \\
\hline & flat & 0.457 & 0.199 & 0.022 & 5.264 & $0.067-0.847$ \\
\hline & funnel shaped teat end & base & & & & \\
\hline \multirow{8}{*}{ Hind teats } & Lactation no. & 0.037 & 0.016 & 0.024 & 5.108 & $0.005-0.068$ \\
\hline & Teat length & 0.018 & 0.003 & $<0.001$ & 34.96 & $0.012-0.024$ \\
\hline & Teat diameter & -0.022 & 0.008 & 0.007 & 7.363 & $-0.038--0.006$ \\
\hline & Teat end shape & & & & & \\
\hline & round & 0.743 & 0.182 & 0.004 & 16.682 & $0.386-1.099$ \\
\hline & pointed & 1.262 & 0.214 & 0.017 & 34.812 & $0.843-1.682$ \\
\hline & flat & 0.459 & 0.189 & 0.015 & 5.912 & $0.089-0.830$ \\
\hline & funnel shaped teat end & base & & & & \\
\hline
\end{tabular}

\subsection{Discussion}

The main objective of this study was to describe the prevalence of teat end hyperkeratosis and some specific animal variables in commercial high-yielding dairy herds and to identify animal variables associated with teat end hyperkeratosis. It was possible to find some animal variables which are associated with teat end hyperkeratosis score. These are lactation number, teat size (diameter, length) and teat end shape.

\subsection{Lactation number}

Animals with hyperkeratosis score 3 had a higher average lactation number than those with score 0 to 2 . The results imply a maximum during the third lactation. Gossen et al. (2007) found that teats of cows in their second lactation to have better average hyperkeratosis scores than younger or older cows [23]. Neijenhuis et al. (2000) described an increase of hyperkeratosis with the lactation number [4].

\subsection{Lactation stage}

Cows with higher teat end hyperkeratosis scores tend to have more days in milk (except for front teats with score 0). Different authors reported an increase in hyperkeratosis with progressing lactation. They found an increase in teat end 
hyperkeratosis score between the first 6 weeks to 4 months of lactation and a subsequent phase of persistency [4, 23, 24]. The development of hyperkeratosis is supposed to be a natural process of adaption of the teat to machine milking. It reaches its maximum after a certain time of exposure to mechanical stress. Neijenhuis et al. (2000) described changes in teat end tissue as a result of mechanical stress during machine milking [4].

Animals examined for the present study with an udder edema had on average lower hyperkeratosis scores. Udder edema typically appears around the time of calving and especially for first calving heifers reaches its maximum a few days after calving [25]. Animals with an udder edema are therefore often only a few days in lactation.

\subsection{Teat length and teat diameter}

Front teats were found to be longer than rear teats $(53.5 \pm 8.1 \mathrm{~mm}$ and $46.4 \pm 7.6 \mathrm{~mm}$, respectively) in the present study. Rasmussen et al. (1998) found an average teat length of $45 \mathrm{~mm}$ for front and $40 \mathrm{~mm}$ for rear teats of first lactation cows. Older animals had teats that were about $10 \mathrm{~mm}$ longer. Their results are very close to the results of the present study.

The teat length was associated with the teat end hyperkeratosis score in front and rear teats. Teats with a score of 3 were on average longer than teats with score 0,1 or 2 . Hubal (2010) found longer teats to have a teat end hyperkeratosis which exceeds the scores 0 and $1(\mathrm{P}<0.001)$, too [26].This may be due to inadequate massage during the milking process and therefore higher mechanical stress for teat ends of longer teats. Wendt et al. (2007) supposed that teat ends of very long or short teats are exposed to a continuous vacuum, because they lie outside optimal massage zone of the liner [13]. A teat length between 50 and $60 \mathrm{~mm}$ is supposed to be optimal $[13,27]$. In the present study it could be found that rear teats had a better teat condition than longer front teats. Mean length of the rear teats was smaller than $50 \mathrm{~mm}$ for all hyperkeratosis scores while the front teats had mean values between 50 and $60 \mathrm{~mm}$, which is the recommended length.

Front teats were also thicker than rear teats $(21.7 \pm 2.6 \mathrm{~mm}$ and $21.3 \pm 2.6 \mathrm{~mm}$, respectively). These results are close to the values found by Bakken (1981) $(21.7 \mathrm{~mm}$ for front teats, $21.4 \mathrm{~mm}$ for rear teats). A clear association between the teat diameter and hyperkeratosis score could not be found. Teats with a score of 0 were on average thicker than those with score 1,2 or 3 , but teats with score 3 were also found to have a tendency to be thicker than those with score 1 or 2 . Cow individual variables like lactation number or lactation stage may have a more dominant influence on hyperkeratosis development than the teat diameter and therefore mask its effect.

\subsection{Teat shape}

The teat shape was found to be very uniform. More than $99 \%$ of all teats scored were classified "normal". Other teat shapes therefore were combined in the category "other shapes". The teat shape was no significant animal variable included in the final regression model.

\subsection{Teat end shape}

The teat end shape was relatively uniform in the examined population of dairy cattle. Round teat ends were found in $81 \%$ of the teats (for both front and rear teats), followed by flat teat ends (13.79\% and $14.13 \%$, respectively) and pointed teat ends (3.81\% and 3.44\%, respectively). Funnel shaped teat ends were seldom (less than $2 \%$ ). The distribution of teat endshapes was different from the findings of Neijenhuis et al. (2000) [4]. Round teat ends were the most common shape with a frequency of $43 \%$ of the examined teats, too, followed by pointed teat ends (31\%). Flat and funnel shaped teat ends ranged behind these forms (13\% each). For the teat end shape a heritability of 0.24 was estimated by Chrystal et al. (2001) [28]. In contrast to the present study, the study of Neijenhuis et al. (2000) was conducted in the Netherlands [4]. Genetic disposition might be an explanation for the different results. Older studies used varying terms and classification systems for the description of teat endshapes which makes it difficult to make a reasonable comparison between results $[14,15]$.

The proportion of pointed teat ends is positively associated with the hyperkeratosis score. Flat teat ends are less likely to have extreme hyperkeratosis. Similar surveillance could be made for funnel shaped teat ends. The higher the hyperkeratosis score, the less often teat ends are funnel shaped. Pointed teat ends were described to be more susceptible for the development of hyperkeratosis by Neijenhuis et al. (2000) [4]. Hyperkeratosis of pointed teat ends got rough earlier in lactation and more frequently than funnel shaped teat tips. The results of other studies confirm this hypothesis $[6,14,16]$. It could be hypothesized that pointed teat ends have less tissue surrounding the teat orifice. Therefore mechanical forces as a consequence of machine milking may affect the teat canal epithelium and the teat end tissue more intensively. In Contrast it is conceivable that the orifice of funnel shaped teat ends is embedded in tissue and is less exposed the milking vacuum. 


\subsection{Short term changes in teat end condition}

Changes in teat skin colour and edema of the teat after milking are the clinical signs of an impaired circulation of blood and lymph. Teat skin colour changes were found for over $40 \%$ of the examined teats. More than $40 \%$ of the teats had an edema of the teat barrel and more than 30\% had an edema of the teat end. Mein et al. (2001) require thresholds of less than $20 \%$ teats with changes in teat skin colour or an edema after milking to assess, if the massage of the liner is adequate to relieve the teat [3]. In the present study liner massage is not effective following these recommendations. Short term changes in teat condition were no significant animal variables with an association to hyperkeratosis but they may give a hint at problems with milking technique which may influence hyperkeratosis development.

\subsection{Hyperkeratosis score}

The thresholds for hyperkeratosis given by Mein et al. (2001) were exceeded in the dairy cattle population involved with the present study [3].More than $50 \%$ of the front teats and more than $45 \%$ of the rear teats had a hyperkeratosis score higher than score 1 (smooth white ring around the teat orifice). As recommended by Mein et al. (2001), less than $20 \%$ of lactating cattle should have one or more teats with a teat end hyperkeratosis score of 2 (rough callous ring around the teat orifice) or 3 (very rough ring) [3]. It is difficult to compare the results with other studies, because the scoring systems used to record hyperkeratosis vary between authors. Lewis et al. (2000) found more than $30 \%$ of the examined 2000 teats to exceed a prone ring and have fronds around the teat orifice [29]. Neijenhuis et al. (2000) used a scoring system with five classes to describe thickness of the hyperkeratosis ring (none, thin, moderate, thick, extreme) and two classes to describe roughness of the ring (smooth and rough) [4]. The system used in the present study was developed to allow a quick and easy classification in the milking parlour and is limited to four classes. It is based on the simplified classification system for routine field evaluations introduced by Mein et al. (2001) [3].

The extent of teat end hyperkeratosis is essentially determined by the forces the milking process exercises on the teat tissue. The longer the teat tissue is affected by mechanical forces, especially in periods with low milk flow ("overmilking"), the higher the risk for the development of severe teat end hyperkeratosis is $[10,11,12]$.

Therefore it is not surprising that front teats in the study were more prone to have higher hyperkeratosis scores. These teats only have about 60 to $70 \%$ of the milk yield that rear teats have [30]. The period front teats are milked with low or without milk flow is much longer than for rear teats [4]. The results of different studies agree with the data presented here[31,4].

In the present study it was found that that cow individual variables lactation number, teat length, teat diameter and teat end shape are associated with teat end hyperkeratosis. The results of the present study indicate that the consideration of teat size and teat end shape of dairy cows may be a suitable instrument to reduce the prevalence of teat end hyperkeratosis in herds. However, the association between milking variables (e.g. machine-on time, milking speed), management variables (e.g. alkalization of bedding material, post milking teat disinfection) and teat end hyperkeratosis were not investigated. Due to the fact that more than $45 \%$ of front and rear teats have rough to very rough callous rings around the teat orifice further research is needed to reduce the prevalence of long-term changes in teat condition in German high-yielding dairy herds.

\section{CONCLUSION}

The development of hyperkeratosis has been described as a natural process of adaption to milking. There are some cow individual factors that influence their severity beside the mechanical forces of the milking process. These are especially teat end shape, teat length and diameter and lactation stage. Teat end condition was poor in the population involved in the present study and may affect udder health. The population examined in this survey was uniform regarding teat end shape and teat size. Breeding selection should continue to prefer animals without extreme teat sizes (too short as well as too long). Also pointed teat tips are not desirable.

\section{ACKNOWLEDGEMENTS}

We would like to thank all farmers participating in the study. We also gratefully acknowledge the financial support of the chamber of agriculture of Lower Saxony and the animal health service of Saxony-Anhalt (SESAM-project).

\section{REFERENCES}

[1] C. Hagnestam-Nielsen, U.Emanuelsen, B. Berglund, E. Strandberg, „Relationship between somatic cell count and milk yield in different stages of lactation" in Journal of Dairy Science 92, pp. 3124-3133, 2009. 
[2] International Dairy Federation (IDF), "Economic consequences of mastitis" in Bulletin of the International Dairy Federation $394 / 2005$.

[3] G.A. Mein, F. Neijenhuis, W.F. Morgan, D.J. Reinemann, J.E. Hillerton, J.R. Baines, I.Ohnstad, M.D. Rasmussen, L. Timms, J.S. Britt, R. Farnsworth, N. Cook, T. Hemling, "Evaluation of bovine teat condition in commercial dairy herds: 1. Non-infectious factors" in 2nd International Symposium on Mastitis and Milk Quality, Vancouver, Canada, pp. 347-351, 2001.

[4] F. Neijenhuis, H.W. Barkema, H. Hogeveen, J.P.T.M. Noordhuizen, "Classification and longitudinal examination of callused teat ends in dairy cows" in Journal of Dairy Science 83, pp. 2795-2804, 2000.

[5] M.D. Rasmussen, "Influence of switch level of automatic cluster removers on milking performance and udder health" in Journal of Dairy Research 60, pp. 287-297, 1993.

[6] F. Neijenhuis, G.H. Klungel, H. Hogeveen, J.P.T.M.Noordhuizen, „Machine milking risk factors for teat end callosity in dairy cows on herd level" in Mastitis in dairy production: current knowledge and future solutions (ed Hogeveen H) 4th IDF International Mastitis Conference, Maastricht, The Netherlands, Pp. 376-382, Wageningen Academic Publishers, Wageningen, The Netherlands, 2005.

[7] J. Hamann, G.A. Mein, S. Wetzel, „Teat tissue reactions to milking: effects of vacuum level” in Journal of Dairy Science 76, pp. 1040-1046, 1993.

[8] D.J. Reinemann, R. Bade, M.Zucali, C.Spanu, P.L.Ruegg, "Understanding the influencence of machine milking on teat defense mechanisms" in Mastitis control - from science to practice, Proceedings of International conference, Wageningen Academic Publishers, pp. 323-331, 2008.

[9] R.D. Bade, D.J. Reinemann, M. Zucali, P.L. Ruegg, P.D. Thompson, "Interactions of vacuum b-phase duration, and liner compression on milk flow rates in dairy cows" in Journal of Dairy Science 92, pp. 913- 921, 2009.

[10] J.E. Hillerton, J.W. Pankey, P. Pankey, "Effect of overmilking on teat condition” inJ. Dairy Research 69, pp. 81-84, 2002.

[11] I.C. Ohnstad, G.A. Mein, F. Neijenhuis, J.E.Hillerton, J.R. Baines, R. Farnsworth, "Assessing the scale of teat end problems and their likely causes" in National Mastitis Council Annual Meeting Proceedings, pp. 128-135, 2003.

[12] C.O. Paulrud, S. Clausen, P.E. Andersen, M.D. Rasmussen, „Infrared thermography and ultrasonography to indirectly C-monitor the influence of liner type and overmilking on teat tissue recovery" in ActaVeterinaria Scandinavica 46, pp. 137-147, 2005.

[13] K. Wendt, S. Köhler, D.Sass, S. Spasovski, E. Piltz, „Einflussfaktoren auf die hämatogene Mikrozirkulation an der Zitze des Milchrindes“ inZüchtungskunde 79, pp. 119-127, 2007.

[14] G. Bakken, "Relationships between udder and teat morphology, mastitis and milk production in Norwegian Red Cattle" in Acta Agriculturae Scandinavica 31, pp. 438-444, 1981.

[15] M. Binde, H. Bakke, „Relationships between teat characteristics and udder health - A field survey” in Nordisk Veterinaer Medicin 36, pp. 111-116, 1984.

[16] F. Neijenhuis, H.W. Barkema, H. Hogeveen, J.P.T.M. Noordhuizen, "Relationship between teat-end callosity and occurrence of clinical mastitis" in Journal of Dairy Science 84, pp. 2664-2672, 2001.

[17] J.E. Breen,M.J. Green, A.J. Bradley, "Quarter and cow risk factors associated with the occurrence of clinical mastitis in dairy cows in the United Kingdom” in Journal of Dairy Science 92, pp. 2551-2561, 2009.

[18] ISO 5707:1996 Milking machine installations - construction and performance

[19] E. Grunert,,Weiblicher Geschlechtsaparat und Euter“, inIn Die klinische Untersuchung des Rindes (eds Dirksen G, Gründer HD, Stöber M) 3. Auflage. pp. 525-529. Verlag Paul Parey, Berlin and Hamburg, 1990.

[20] D. Urban, „Logit-Analyse: Statistische Verfahren zur Analyse von Modellen mit qualitativen Response-Variablen“. Stuttgart, Germany: Fischer, 1993.

[21] M.J. Slakter, "A Comparison of the Pearson chi-square and Kolmogorov Goodness-of-Fit tests with respect to validity" in Journal of the American Statistical Association 60, pp. 854-858, 1965.

[22] N.J.D. Nagelkerke, "A note on the general definition of the coefficient of determination" in Biometrica 78, pp. 691-692, 1991.

[23] N. Gossen, N. Potrafki, M. Hoedemaker, "Beziehungen zwischen tierspezifischen Faktoren und der Zitzenkondition von Milchkühen“ inTierärztliche Umschau 62, pp. 354-363, 2007.

[24] M.F.H. Shearn, E. Hillerton, "Hyperkeratosis of the teat duct orifice in the dairy cow" in Journal of Dairy Research 63, pp. 525-532., 1996.

[25] W.Heeschen, „Die Milchdrüse während der Gravidität, Laktation, Puerperium sowie Milchmangel“, in Tiergeburtshilfe (eds Richter J, Arbeiter K) 4. Auflage. pp. 123- 128. Verlag Paul Parey, Berlin and Hamburg, 1993.

[26] M. Hubal, „Untersuchungen zum Einfluss melktechnischer Parameter auf die Zitzenkondition von Milchkühen“. Göttingen, GeorgAugust- Univ., Fak. für Agrarwissenschaften, Diss 2010.

[27] M.D. Rasmussen,E.S.Frimer, L. Kaartinen, N.E. Jensen, „,Milking performance and udder health of cows milked with two different liners" in Journal of Dairy Research, 65, pp. 353-363, 1998.

[28] M.A. Chrystal, A.J. Seykora, L.B. Hansen, A.E. Freeman, D.H. Kelley, M.H. Healey, "Heritability of teat-end shape and the relationship of teat-end shape with somatic cell score for an experimental herd of cows" in Journal of Dairy Science, 84, pp. 25492554, 2001.

[29] S. Lewis, P.D. Cockcroft, R.A. Bramley, P.G.G. Jackson, "The likelihood of subclinical mastitis in quarters with different types of teat lesions in the dairy cow", in Cattle Pract., Vol 8, Part. 3, pp. 293-299, 2000.

[30] D. Weiss, M.Weinfurtner, R.M. Bruckmaier, "Teat anatomy and its relationship with quarter and udder milk flow characteristics in dairy cows" in Journal of Dairy Science, 87, pp. 3280-3289, 2004.

[31] R.L. Sieber, R.J. Farnsworth, "Prevalence of chronic teat-end lesions and their relationship to intramammary infection in 22 herds of dairy cattle," in Journal of the American Veterinary Medical Association, 178, pp. 1263-1267, 1981. 